\author{
Маріанна Леврінц \\ Закарпатський угорський \\ інститут ім. Ракоці Ференца II \\ ORCID ID 0000-0002-2206-7113 \\ DOI 10.24139/2312-5993/2020.02/265-276
}

\title{
СИСТЕМА ПІДГОТОВКИ ВЧИТЕЛІВ ІНОЗЕМНИХ МОВ У США
}

Метою статті $\epsilon$ висвітлення структури, властивостей, елементів, компонентів, ознак і принципів системи підготовки вчителів іноземних мов у США. У дослідженні застосовано метод системного аналізу. Структуру системи підготовки вчителів-фрілологів складає мережа закладів освіти. Система функціонує на різних рівнях вищої освіти. Властивостями системи філологічної освіти $\epsilon$ відкритість, динамічність, цілеспрямованість, адаптивність і децентралізованість; ії елементами є цілі й завдання системи педагогічної освіти, зміст і мета навчання в університетах, форми організації освітнього процесу, дидактичні підходи, принципи навчання, засоби і способи здобування освіти, результати тощо. Компонентами системи є цільовий, ціннісний, нормативно-правовий, організаційно-процесуальний, змістовий, оцінювально-результативний і концептуальний.

Ключові слова: система підготовки вчителів іноземних мов, університет, здобувач вищої освіти, освітня програма, іншомовна освіта, США.

Постановка проблеми. У період розбудови вітчизняної системи вищої освіти, пошуку оптимальних рішень модернізації ії ланок, вагомості набувають зарубіжні педагогічні студії. У цьому контексті інтерес становить вивчення досвіду системи вищої педагогічної освіти США з огляду на визнання її здобутків на світовій освітній арені.

Аналіз актуальних досліджень. На підставі аналізу стану дослідженості проблеми підготовки педагогічних фахівців у США з'ясовано, що дотичні питання вивчалися О.Зіноватною, М.Іконніковою, І.Литовченко, Т. Кошмановою, О. Стойкою, С. Шандрук, К. Шихненко та ін. Серед американських дослідників цю проблему вивчали Л.Дарлінг-Геммонд, К. Джонсон, Д. Кауфман, Дж. Кренделл, Б. Кумарадівелу, Д. Фрімен та ін. Водночас, зважаючи на швидкоплинність освітніх процесів сьогодення, постає необхідність перегляду й узагальнення наявного науково-практичного доробку та подальшого опрацювання виділеної проблеми.

Метою статті $\epsilon$ всебічне вивчення системи підготовки вчителів іноземних мов у США: її структури, властивостей, елементів, компонентів, ознак і принципів.

Методи дослідження. У дослідженні застосовано підходи системного аналізу: системно-елементний, системно-структурний, системно-цільовий, системно-функціональний і системно-історичний.

Виклад основного матеріалу. Фахова підготовка вчителів іноземних мов (IM) є підсистемою національної системи вищої освіти та педагогічної освіти США, вектор розвитку якої задається кластерами зовнішніх 
опосередкованих і внутрішньогалузевих чинників, які визначають унікальність її системотворчих характеристик. На підставі ретроспективного аналізу з'ясовано, що ознак системності галузь підготовки вчителів IM у США почала набувати на початку XX ст. із появою інституціоналізованих освітніх програм навчання вчителів-лінгвістів (Schulz, 2000), надалі еволюціонуючи паралельно з соціокультурним, політико-економічним і науково-технічним розвитком американського суспільства.

Інтеграційними властивостями системи підготовки вчителів IM (СПВІМ) США є: відкритість, що виявляється у взаємодії означеної системи $з$ іншими суспільними інститутами й організаційними формами; динамічність, оскільки СПВІМ зазнає неперервного розвитку, трансформаційних змін, оновлень під дією реформувальних ініціатив; цілеспрямованість, рефлексія на суспільні потреби й запити; адаптивність або гнучкість, видозмінюваність і модифікація внаслідок упливу зовнішніх і внутрішньо зумовлених чинників; децентралізація, що знаходить відображення в значній автономності управління закладами освіти.

Децентралізація як провідна властивість американської системи педагогічної освіти наділяє її низкою переваг, незважаючи на деякі труднощі, пов'язані із ії координуванням і управлінням. Диверсифікованість закладів освіти, сформована внаслідок децентралізованого управління, $\epsilon$ корисною для системи вищої освіти США у трьох аспектах: інституційному, суспільному й системному. Диверсифікованість із інституційних позицій є рефлексія на потреби студентів, включаючи різнорідні навчальні програми, студентський корпус, освітні стандарти. Система вищої освіти входить до ієрархії інших суспільних систем, відтак, диверсифікованість освітньої системи служить широким суспільним і політичним інтересам, зокрема, соціальній мобільності ії суб'єктів. У розрізі теорії систем вища освіта $є$ відкритою системою, у якій функціонують індивіди з різних соціальних та етнічних прошарків населення. Різнорідний склад молоді з вищою освітою, на противагу гомогенному, здійснює особливий уплив на соціальні процеси в країні, а також диферентний склад компонентів захищає стабільність функціонування системи, роблячи ї̈ більш адаптивною й ефективною в контексті сучасних викликів (Thelin et al, 2002).

Системотвірними елементами системи підготовки вчителівфілологів $\epsilon$ : цілі й завдання системи педагогічної освіти загалом і підготовки вчителів IM в університетах зокрема; зміст і мета навчання в закладах вищої освіти і вивчення конкретних дисциплін; форми організації навчального процесу, підходи до формування професійних компетентностей, принципи підготовки вчителів-філологів; засоби й способи здобування фахової філологічної і педагогічної освіти; освітній процес і його результати як конвергенція теоретичних i практичних аспектів професійного становлення. 
Компонентами досліджуваної системи $€$ цільовий, ціннісний, нормативно-правовий, організаційно-процесуальний, змістовий, оцінювально-результативний і концептуальний.

Нормативно-правовий компонент системи педагогічної освіти США представлений законодавчо-нормативною документальною базою федерального або загальнонаціонального рівня Департаменту освіти США, імплементація якої належить до компетенції штатових і муніципальних урядових структур.

Загальнонаціональна освітня політика формується федеральним урядом США актами Конгресу «Кодекс законів США» (розділ 34). Спираючись на децентралізацію як основний принцип регулювання системи вищої освіти, освітня політика закладів освіти затверджується уповноваженими органами штатів. Зважаючи на значну автономність американської освітньої галузі у прийнятті важливих рішень щодо управління й організації освітніх процесів, система освіти в кожному штаті $\epsilon$, певною мірою, унікальною, вирізняючись широким діапазоном закладів освіти, цілей, завдань і змістовими підходами.

Релевантними у світлі регулювання професійної підготовки вчителів IM є законодавчі акти й урядові постанови: Закон «Про вищу освіту» (1965), поправки й доповнення до означеного закону, які зазвичай вносяться кожні п'ять років. Розгляду проблеми підвищення якості педагогічної праці присвячено окремий розділ закону - Розділ II «Підвищення якості педагогічної праці». Розділом IV «Міжнародні освітні програми» визначено нормативно-правові підстави для забезпечення студентів філологічних спеціальностей можливостями навчатись у країнах, мова яких вивчається.

Вектор федеральної освітньої політики США визначає провідні цілі підготовки вчителів, згідно з якими якісна підготовка педагогів $\epsilon$ передумовою продуктивної професійно-педагогічної діяльності й зростання академічної результативності (Skyses \& Dibner, 2009). На підставі аналізу нормативної та фахової літератури з'ясовано, що у визначенні мети підготовки вчителів американська науково-освітня громадськість спирається на проблему якості професійно-педагогічної діяльності.

За визначенням Департаменту освіти США, програмою підготовки вчителів $€$ затверджений державою навчальний курс, завершення якого свідчить про виконання кандидатом усіх вимог навчальної підготовки, які наділяють його первинними повноваженнями викладати в середній школі (К-12). 3 початку XX ст. підготовка педагогів відбувається в закладах вищої освіти. Фахова підготовка майбутніх учителів IM здійснюється спільними діями кафедр або спеціалізованих підрозділів 3ВО прикладної лінгвістики, педагогіки або мови й літератури ЗВО. До означеного періоду формальна підготовка вчителів провадилася на базі так званих «нормальних шкіл», де випускників старшої школи готували до виконання педагогічних функцій. 
На початку XX ст. при університетах було засновано педагогічні коледжі шляхом об'єднання нормальних шкіл (Kuenzi, 2018, с. 2).

Організаційно-процесуальний компонент СПВІМ в університетах США характеризується відкритістю, динамічністю й гнучкістю, взаємодіючи та адаптуючись під дією різновекторних суспільно-історичних, політикоекономічних та інших чинників, а також цілеспрямованістю, реагуючи на запити й соціальне замовлення поліетнічного населення країни.

На відміну від раціонально організованої системи початкової і середньої освітніх ланок, системі вищої освіти США притаманна певна функціонально-структурна поліморфність, сформована внаслідок децентралізації, автономності іï менеджменту та інших внутрішньо суспільних процесів. Поліморфність, як якість системи вищої освіти, ускладнює категоризацію й класифікацію типів установ післяшкільної освіти, принципів їхньої організації й управління.

Підготовка вчителів-філологів здійснюється за освітньо-професійними та освітньо-науковими програмами на всіх рівнях вищої освіти: початковому (короткому), першому (бакалаврському), другому (магістерському) та третьому (освітньо-науковому). Оскільки працевлаштування на посаду вчителя IM вимагає принаймні диплома бакалавра в галузі іноземної філології та педагогічної освіти, короткий цикл (дворічний) вищої освіти $\epsilon$ тільки транзитарним, який веде до першого освітнього рівня або вище. Підготовку педагогічних фахівців ступеня бакалавр (undergraduate переддипломний) та магістра (graduate - випускний) в галузі філології проводять університети й коледжі, дослідницькі університети I і II категорії, докторські університети, загальноосвітні університети.

Установлено, що фахова підготовка вчителів відбувається за традиційною й альтернативною моделями. Станом на 20141497 освітніх закладів (69 \%) складали традиційні освітні програми, а решта альтернативні, із яких 473 освітні установи (22 \%) - альтернативні програми підготовки вчителів, які базуються на ЗВО і 201 освітня установа (9 \%), що функціонує незалежно від ЗВО. Типові традиційні освітні програми передбачають принаймні 100 годин педагогічної практики в супроводі досвідченого фахівця-ментора, тоді як в альтернативних програмах означена вимога не ставиться перед здобувачем педагогічної освіти (Kuenzi, 2018, с. 3-5).

Інституційні форми здобуття вищої освіти педагогічного спрямування у США передбачають очну (full-time), заочну (part-time), дистанційномережеву та комбіновану, що поєднує кампусне та онлайнове навчання. Увагу привертає факт нерівномірного розподілу кількості студентів між ними. Так, згідно зі статистичними даними, дві наймасовіші програми підготовки педагогів, за якими навчались 30000 слухачів, $€$ мережеві (Grand Canyon University, the University of Phoenix) (U.S. Department of Education, 2016, c. XVI). 
Американська система підготовки майбутніх учителів IM $\epsilon$ багаторівневою, що виявляється в ієрархії освітньо-кваліфікаційних рівнів, та багатоваріантною з огляду на наявність кількох видів освітніх педагогічних програм. Процес професійного становлення вчителя IM може відбуватися згідно з такими рівнями: асистент учителя IM (associate's degree) - термін навчання 2 роки; бакалавр у галузі викладання IM - термін навчання 4 роки; магістр - термін навчання 1-2 роки; доктор філософії термін навчання 1-2 роки; додатковий сертифікат учителя IM (certificate) термін навчання 1 рік.

Багатоваріантність у підготовці вчителів IM полягає в різних змістових траєкторіях здобуття лінгвістичної й педагогічної освіти. Зокрема, у США на вибір студентів факультетів IM фаховий педагогічний компонент можна вивчати за двома напрямами, що дає право на здобуття диплома бакалавра/магістра наук з викладання IM (Bachelor/Master of Science in Language Teaching) та бакалавра/магістра мистецтв у викладанні IM (Bachelor/M aster of Arts in Language Teaching), які суттєво відрізняються за організаційно-змістовими підходами.

Завдяки реалізації принципів диференціації та індивідуалізації студентам надаються широкі можливості поєднувати або комбінувати різні освітні програми і курси як по вертикалі, так і по горизонталі, тобто курси професійно-педагогічного спрямування можна вивчати як на рівні бакалаврату, так і на рівні магістратури. Практикується також паралельне вивчення кількох освітніх програм і курсів. Допомогу у виборі індивідуальної навчальної траєкторії студентам надає особистий консультант, який обирається 3 професорсько-викладацького складу факультету. Забезпечення прохідності за освітніми рівнями і програмами відбувається завдяки трансферу навчальних кредитів, які зараховуються внаслідок успішного проходження навчальних курсів або отримання документа, що засвідчує освітній рівень (сертифікат, диплом).

Студенти університетів можуть обирати основну спеціальність (major), додаткову (minor), або навіть дві основні (double major), здебільшого по завершенню другого курсу. Перші чотири семестри студенти філологічних спеціальностей зазвичай навчаються за однаковим курикулумом, вивчаючи одні й ті самі навчальні дисципліни, головною метою яких $є$ розвиток мовних і мовленнєвих компетентностей, і деякі загальноосвітні дисципліни. Починаючи з п'ятого семестру, в багатьох університетах відбувається профільне навчання з обраної спеціалізації. Навчальні курси, включені до курикулумів перших чотирьох семестрів, належать до категорії нижчого рангу (lower division), тоді як 5-8 семестрів - до категорії вищого рангу (higher division). Наприклад, в Університеті Вебера студентам пропонуються такі освітні програми згідно зі спеціалізацією: основна спеціальність у галузі IM (a regular major), основна спеціальність у галузі викладання IM (a teaching 
major), основна спеціальність з акцентом на французькій, німецькій, іспанській мовах для комерційних цілей (a major with a commercial emphasis in French, German or Spanish). На факультеті також готують фахівців за основною або додатковою спеціальністю в галузі викладання IM; пропонуються міждисциплінарні додаткові галузі спеціалізації, як наприклад, лінгвістика, латиноамериканські студії, азійські, європейські студії (Weber State University; Oklahoma State University).

Зважаючи на значну автономність закладів вищої освіти, їхнє різноманіття й конкурування у США, відсутня єдина система вимог до абітурієнтів. Порядок зарахування вступників на лінгвістично-педагогічні спеціальності встановлюється в індивідуальному порядку урядами штатів, округів або закладів освіти. Підставою для зарахування на перший курс для бакалаврів може слугувати врахування таких критеріальних вимог: транскрипт (перелік предметів, які вивчав абітурієнт), середній бал свідоцтва про середню освіту, середній бал за вивчення фахових дисциплін (у зазначеному випадку з іноземної мови), стандартизований вступний тест ACT або SAT, стандартизовані тести, що оцінюють базові знання і вміння, фахове випробування з IM, рекомендаційні листи, есе або виклад особистої філософії, інтерв'ю. Найпоширенішими вимогами, визначеними на рівні штатів або 3ВО, є середній бал атестата про середню освіту, транскрипт, мінімальна кількість курсів і кредитних годин (U.S. Department of Education, 2016, с. 5). Терміни зарахування студентів визначаються університетами в індивідуальному порядку й відбуваються два або три рази на рік.

Аналіз статистичних даних, представлених у щорічних звітах Національного центру освітньої статистики Департаменту освіти США, засвідчує стабільність тенденції до зростання кількості слухачів спеціальностей лінгвістика загалом і програм підготовки вчителів IM зокрема за період 1960-2015 роки. Водночас, протягом останніх кількох років (2015-2019) число бажаючих навчатися за лінгвістичним напрямом дещо зменшилася. Кількість дипломів бакалавра, наданих майбутнім учителям IM, зросла у 2,5 рази порівняно з 1960-х роками XX ст. Пік популярності означеної спеціальності припадає на кінець 1960-х, 1980-х, на початок 1990-х років (M LA Teagle Foundation Working Group, 2009, с. 298-299).

Освітні програми, за якими присвоюється ступінь бакалавра в галузі іноземної філології та вчителя IM, включають 44 напрями спеціалізації згідно з профільною ІМ. Станом на 2004-2005 роки переважна більшість дипломів із загальної кількості була надана майбутнім учителям іспанської мови $(47,8$ \%), французької мови (13,8 \%), німецької мови $(6,3 \%)$, загальної лінгвістики (5,9\%), класичних мов і літератури (5,3\%). Відсотковий розподіл, згідно з освітніми рівнями вчителів-філологів для рівня бакалавр, становить 52,2 \%, магістр - 34,8 \%, доктор філософії - 6,1 \%, ще 6,1 \% дипломованих фахівців продовжили навчання не за педагогічним фахом. 
Показовими є дані про працевлаштування випускників факультетів IM. Найбільше число дипломованих фахівців розпочало професійну кар'єру саме за фахом на посаді вчителя початкової й середньої школи (25,3 \%), ще 5,2 \% працюють у закладах післясередньої освіти (postsecondary teacher: foreign language) на посадах учителя IM і 1,3 \% - учителя інших шкільних дисциплін; 8,6 \% змінили фах, надавши перевагу галузі медицини, 8,4 \% економіки й торгівлі, 7,6 \% займають адміністративні посади, 5,6 \% працюють у галузі комп'ютерних технологій тощо (The Linguistic Society of America, 2017, с. 25-27).

Зміст підготовки вчителів IM інтегрує загальноосвітню, соціальногуманітарну, іншомовну, лінгвістичну, літературознавчу, культурологічну, інформаційно-технологічну, психолого-педагогічну і лінгводидактичну складові. Аналіз курикулумів програм підготовки бакалаврів іншомовної освіти виявив, що перелічені змістові характеристики представлені такими блоками дисциплін: загальноосвітні (core curriculum), предметноорієнтовані (content core, major requirements), професійно-орієнтовані (pedagogical core, teacher education courses).

Оцінювально-результативний компонент посідає важливе місце в американській системі філологічної освіти: оцінювання $\epsilon$ не лише частиною ліцензування й сертифікації, а й стимулює навчальну активність студентів, професійне зростання й розвиток майбутніх учителів (Cochran-Smith, 2005).

Оцінювання в підготовці вчителів IM $\epsilon$ наскрізним елементом, комбінуючи поточне і сумативне оцінювання знань студентів викладачами навчальних дисциплін; оцінювання результатів науково-дослідницької діяльності; оцінювання успішності навчально-професійної діяльності керівниками педагогічної практики і відповідальними викладачами університетів; оцінювання рівня сформованості іншомовної компетентності; підсумкове оцінювання, що відкриває доступ до педагогічного компонента освітньої програми; оцінювання, що є підставою для доступу до практики у викладанні (teacher internship); ліцензування, яке надалі включає: а) фаховий іспит для вчителів (наприклад, PRAXIS - Principles of Learning and Teaching Exam - принципи навчання і викладання); б) іспит зі спеціальності, для прикладу «Інтерв'ю для визначення рівня оволодіння усним мовленням» (the ACTFL Oral Proficiency Interview, OPI, Praxis Content Area Exam); в) Педагогічне портфоліо (Performance Teaching Portfolio) (Wichita State University).

Релевантними концептуальними напрямами педагогічної іншомовної освіти США є гуманізм, неопрагматизм, конструктивізм, соціалконструктивізм, критична педагогіка, епістемологія постпозитивізму та соціокультурна парадигма.

Системі підготовки вчителів IM у США притаманною $\epsilon$ низка інтеграційних, взаємозв'язаних ознак, що визначають її самобутність на тлі глобалізаційних освітніх і лінгвальних явищ. 
Диверсифікованість та інклюзивність є одним із ключових орієнтирів розбудови національної системи педагогічної освіти, що передбачає рівноправне забезпечення умов здобуття вищої освіти всіма членами суспільства незалежно від етнічної й расової належності, соціального статусу або стану здоров'я. За підтримки федерального уряду Департаментом освіти США розробляються рекомендації щодо реалізації диверсифікації й інклюзивності в освітньому процесі ЗВО, надається технічна й значна матеріальна допомога у вигляді грантів. Утвердженню диверсифікації й інклюзивності в освіті сприяє широка суспільна зацікавленість проблемою: десятки організацій займаються вивченням перебігу впровадження доступу до вищої освіти менш привілейованої молоді (U.S. Department of Education, 2016, с. 6-7). 3 іншого боку диверсифікація СПВІМ виявляється в наявності розгалуженої мережі закладів освіти, розмаїтті освітніх програм, послуг, спеціальностей, інституційних форм здобуття вищої освіти, варіативності й елективності змісту навчальних програм, міждисциплінарності.

Заснована на концепції ціложиттєвого навчання, характерною ознакою СПВІМ $є$ неперервність, поділена на такі етапи: 1) профорієнтація й допрофесійна підготовка; 2) базова педагогічна освіта, що здійснюється закладами вищої освіти і дає можливість отримання диплома бакалавра, магістра; 3) входження у професію початкуючого вчителя (teacher induction); 4) професійний розвиток у системі підвищення кваліфікації та самоосвіта вчителів.

Властивими ознаками СПВІМ у США є персоналізація та споріднені їй індивідуалізація й диференціація. Під персоналізованим навчанням американські вчені розуміють планування освітнього процесу 3 урахуванням сильних сторін, потреб та інтересів студентів, надаючи їм право вибору змісту навчання, способів, темпів і часу, таким чином забезпечуючи гнучкість освітнього процесу й підтримку заради розкриття особистого потенціалу кожного студента (Patrick et al, 2013).

Стандартизація. В американській СПВІМ відбувається активний перехід на стандартно-базовану освіту. Поштовхом до розгортання кампанії із запровадження освітніх стандартів стало прийняття урядової Постанови «Не залишимо жодної дитини без уваги» (2001), націленої на підвищення рівня освіченості американських громадян шляхом запровадження системи підзвітності. Стандарти в педагогічній освіті регламентують вимоги до фахової підготовки й розвитку вчителів, а також $\epsilon$ інструментом контролю за якістю педагогічної освіти.

Фундаменталізація, що отримує значне висвітлення в американському науковому дискурсі, передбачає зближення теоретичних i практичних компонентів у СПВІМ, забезпечуючи плавність транзиту від навчальної до професійно-педагогічної діяльності майбутнього вчителя. 
Зокрема у США практикується систематична підтримка початкуючих учителів (teacher induction), спрямована на оптимізацію адаптації педагога до реалій професійної діяльності та зменшення показників звільнень.

Засадничою ознакою СПВІМ у США є інформатизація і технізація, пов'язані зі стрімким розвитком інформаційних технологій та їхнім розповсюдженим застосуванням для освітніх цілей. У ході аналізу джерельної бази з'ясовано, що формування компетентності із організації освітнього процесу із застосуванням інформаційних технологій регламентується як нормативними документами стандартів підготовки вчителів IM, так і знаходить відображення в різноплановій навчальнометодичній документації ЗВО.

Колаборація у СПВІМ передбачає організацію освітніх процесів на засадах співпраці й партнерства між ії учасниками, досягнення загальних освітніх цілей засобами колективних дій, розв'язання проблем спільними зусиллями. Саме така організаційна форма сприяє гармонізації функціонування американської освітньої системи.

Розглянемо основні принципи, на які спирається сучасна система педагогічної освіти США, а саме принципи автономії і демократії, академічної свободи, академічної мобільності, конкурентності та економічної доцільності. Принцип інституційної автономії і демократії полягає в самостійності й відповідальності установ вищої освіти у провадженні освітньої діяльності та уповноваженості у прийнятті управлінських рішень. Американські 3ВО функціонують незалежно від федерального уряду і відзначаються високим рівнем децентралізації. Принцип академічної свободи полягає в наданні прав суб'єктам освітнього простору здійснювати професійно-педагогічну, науководослідну, творчо-пошукову та навчальну діяльність на засадах свободи думки, слова, толерантності, взаємоповаги, інклюзії тощо. Американська система освіти забезпечує майбутніх учителів можливостями вибору індивідуальної навчальної траєкторії, пропонуючи широкий діапазон освітніх моделей, спеціальностей, спеціалізацій, навчальних курсів, типів освітніх установ, темпів здобуття вищої освіти тощо. Сучасний стан СПВІМ характеризує значна академічна мобільність студентів і професорськовикладацького складу, передбачаючи перспективи оптації закладів освіти з урахуванням індивідуальних преференцій. Принцип конкурентності та економічної доцільності $є$ дієвим чинником підвищення якості освітніх послуг i продуктивності освітніх процесів. У США інструментарієм регулювання матеріальних уливань та фінансової підтримки як непрямих засобів упливу з боку держави на ефективність функціонування освітньої системи є формування різнорідних рейтингів і проведення конкурсів.

Висновки та перспективи подальших наукових розвідок. Розбудова СПВІМ у США зумовлюється об'єктивними потребами американського суспільства, прогресом наукової думки, державною освітньою й мовною 
політикою, а також загальносвітовими глобалізаційними процесами. Структура СПВІМ утворена підпорядкованою, взаємозв'язаною мережею закладів освіти (університети, коледжі, наукові центри, центри професійного розвитку тощо), профільних галузевих організацій, дорадчих органів, управлінських органів, органів акредитації, які покликані забезпечувати повноцінне функціонування системи підготовки вчителів-лінгвістів. СПВІМ включає освітні рівні бакалавра, магістра, доктора філософії, сертифікаційні програми, систему професійного розвитку вчителів IM, заснованих на засадах ціложиттєвого навчання. СПВІМ має полікомпонентну структуру, охоплюючи цільовий, ціннісний, нормативно-правовий, організаційно-процесуальний, змістовий, оцінювально-результативний і концептуальний компоненти. Властивостями американської системи філологічної освіти, які сприяють когерентності й діалектичній взаємопов'язаності, $€$ відкритість, динамічність, цілеспрямованість, адаптивність та децентралізованість. Інтегративними елементами СПВІМ уважаємо цілі й завдання системи педагогічної освіти, зміст і мету навчання в університетах, форми організації навчального процесу і професійного розвитку, підходи до формування професійної компетентності, принципи навчання, засоби і способи здобування фахової освіти, освітній процес і його результати.

Перспективним напрямом дослідження вважаємо компаративний аналіз американської й української систем підготовки вчителів-філологів 3 метою оновлення вітчизняної системи вищої освіти.

\section{ЛІТЕРАТУРА}

Cochran-Smith, M. (2005). The new teacher education: For better or for worse? Educational Researcher, 34 (7), 3-17.

Kuenzi, J. (2018). Teacher Preparation Policies and Issues in the Higher Education Act. Congressional Research Service. CPS Report. Retrieved from: https://crsreports.congress.gov

MLA Teagle Foundation Working Group (2009). Report to the Teagle Foundation on the undergraduate major in language and literature. Profession, 1, 285-312.

Oklahoma State University. Department of Languages and Literatures. Retrieved from: https://languages.okstate.edu/

Patrick, S., Kennedy, K., Powell, A. (2013). Mean what you say: Defining and integrating personalized, blended and competency education. Vienna, VA: iNACOL. Retrieved from: $\quad$ https://www.inacol.org/resource/mean-what-you-say-defining-andintegrating-personalized-blended-and-competency-education/

Schulz, R. A. (2000). Foreign language teacher development: MLJ Perspectives 1916-1999. M odern Language Journal, 84, 495-522.

Sykes, G., Dibner, K. (2009). Fifty years of federal teacher policy: An appraisal. Center on Education Policy: Washington, DC.

The Linguistic Society of America (2017). The State of Linguistics in Higher Education. Annual Report. Fifth Edition. Washington, DC: Linguistic Society of America.

Thelin, J. R., Edwards, J. R., M oyen, E., Berger, J. B., Vita Calkins, M. (2002). Higher Education in the United States. Encyclopedia of Education. Retrieved from: https:// education.stateuniversity.com/ 
U.S. Department of Education. Office of Planning, Evaluation and Policy Development and Office of the Under Secretary (2016). Advancing Diversity and Inclusion in Higher Education. Washington, D.C. Retrieved from: http:// www2.ed.gov/rschstat/research/pubs/advancing-diversity-inclusion.pdf.

U.S. Department of Education. Office of Postsecondary Education (2016). Preparing and Credentialing the Nation's Teachers: The Secretary's 10th Report on Teacher Quality. Washington, D.C. Retrieved from http://www2.ed.gov/about/reports/annual/teachprep/index.html

Weber State University. Department of Foreign Languages. Retrieved from: https://catalog. weber.edu/preview_entity.php?catoid=17\&ent_oid=3247

Wichita State University. Teacher education student handbook. Retrieved from: www.wichita.edu/education

Шихненко, К. (2018). Розвиток лідерського потенціалу вчителів в умовах змін: досвід реформування шкільної освіти В США. Педагогічні науки: теорія, історія, інноваційні технології, 9 (83), 69-79 (Shykhnenko, K. (2018). Developing the leadership potential of teachers under the conditions of educational change: Lessons from school reforms in the USA. Pedagogical sciences: theory, history, innovative technologies, 9 (83), 69-79).

\section{PEЗЮME}

Левринц Марианна. Система подготовки учителей иностранных языков в США. Целью статьи является изучение структуры, свойств, элементов, компонентов, признаков и принципов системы подготовки учителей иностранных языков в США. В исследовании применен метод системного анализа. Свойствами системы филологического образования является открытость, динамичность, целеустремлённость, адаптивность и децентрализованность; ее элементами являются цели и задачи системы педагогического образования, содержание и цель обучения в университетах, формы организации образовательного прочесса, дидактические подходы, принципы обучения, средства и способы получения образования, результаты и т.д. Компонентами системы являются целевой, ценностный, нормативно-правовой, организационно-процессуальный, содержательный, оценочно-результативный и концептуальный.

Ключевые слова: система подготовки учителей иностранных языков, университет, соискатель высшего образования, образовательная программа, иноязычная образование, США.

\section{SUMMARY}

Levints (Lörinc) Marianna. The system of foreign language teacher education in the USA.

The paper is devoted to the study of the structure, characteristics, elements, components, features and principles of the system of foreign language teacher education in the USA. To this end, the method of systematic analysis was employed. The development of the American system of language teacher preparation has been impacted by the societal needs for foreign language specialists, the educational and language policy, scientific advancements, and general globalizing trends. The structure of the teacher education system is formed by a network of education institutions (universities, colleges, scientific centers, centers of professional development, etc.), professional organizations, advisory bodies, governing bodies, accreditation bodies. The system of teacher preparation includes the educational levels of a bachelor, master, doctor of philosophy, certification programs undergirded by the idea of lifelong learning. It has a multicomponent structure, covering legal, target, regulatory, organizational-procedural, curricular, evaluative, and conceptual 
components. Features of the US system of language teacher preparation that promote its coherence and dialectical interconnectivity are openness, dynamism, purposefulness, adaptability and decentralization. The system's integrative elements are the goals and objectives of teacher preparation, the content and purpose of the university course of study, forms of organization of the processes of education and professional development, approaches to the professional competence development, didactic principles, means and ways of obtaining higher education, the educational process and its results. The underlying principles of foreign language teacher preparation are diversity and inclusion, lifelong learning, personalization together with related to it individualization and differentiation, standardization, fundamentalization, the spread of information technologies in education, collaboration, autonomy, academic integrity, academic mobility, competition and others.

Key words system of foreign language teacher education, university, teacher candidate, educational program, foreign language education, USA.

удк 378.091.2:615.83(477+71) (045)

Інна Мордвінова

Сумський державний університет ORDCID ID 0000-0002-0759-0360

Аліна Ольховик

Сумський державний університет ORDCID ID 0000-0003-0114-1190 DOI 10.24139/2312-5993/2020.02/276-285

\section{ПОРІВНЯЛЬНА ХАРАКТЕРИСТИКА СИСТЕМИ ПІДГОТОВКИ БАКАЛАВРІВ СПЕЦІАЛЬНОСТІ «ФІЗИЧНА ТЕРАПІЯ В УКРАЇНІ ТА КАНАДІ}

у статті висвітлено професійну підготовку бакалаврів «фізичної терапії» в Україні та Канаді. Дана спеціальність вимагає від майбутніх спеціалістів комплексного підходу під час здійснення своєї професійної діяльності. Спеціаліст із фізичної терапії повинен компетентно вміти проводити фізіотерапевтичне обстеження, здійснювати аналіз отриманих даних, установлювати фізіотерапевтичний діагноз, проводити фізіотерапевтичні заходи й оцінку їх ефрективності, працювати в мультидисииплінарній команді. Доведено, що вітчизняна модель підготовки має відмінності від канадської моделі, що грунтуються на принципах організації, фінансування, професійного етикету, самодисципліни спеціалістів на відміну від канадської, де за основу взято мультидисциплінарний підхід.

Ключові слова: фізична терапія, студент, програми, професійна підготовка, фізіотерапевтична діяльність, мультидисциплінарний підхід.

Постановка проблеми. В епоху глобальної соціальної, економічної та демографічної кризи особливо актуальним $€$ питання щодо рівня здоров'я населення, його збереження й покращення, що на даний час $€$ медикосоціальною проблемою, яка вимагає негайного вирішення. У сучасному житті виникає потреба в удосконаленні організації вітчизняної системи підготовки майбутніх спеціалістів з фізичної терапії.

Головними проблемами підготовки спеціалістів даної професії на теперішній час $€$ відсутність на державному рівні освітніх стандартів підготовки та можливості працевлаштування в закладах охорони здоров'я (Приступа, 2011, с. 92-96). 